\title{
Examining of Health Policy in Rare Diseases in Terms of Historical Perspective in Turkey
}

\author{
Merve Deniz PAK GÜRE ${ }^{1}$, Özgür İNCE ${ }^{2}$
}

\begin{tabular}{|c|c|}
\hline $\begin{array}{r}\text { Corresponding Author } \\
\text { Merve Deniz PAK GÜRE } \\
\text { DoI } \\
\text { https://10.48121/jihsam.874683 } \\
\text { Received } \\
04.02 .2021 \\
\text { Accepted } \\
17.06 .2021 \\
\text { Published Online } \\
27.10 .2021 \\
\text { Key Words } \\
\text { Rare diseases } \\
\text { Orphan drugs } \\
\text { Health policy } \\
\text { Healthcare services }\end{array}$ & $\begin{array}{l}\text { Compared with other common diseases in the general } \\
\text { population, a rare disease is a health condition that affects a } \\
\text { small number of people. The progressive, life-threatening and } \\
\text { multi-dimensional nature of these diseases requires the } \\
\text { development of an effective health policy. The aim of this study } \\
\text { is to examine health policy for rare diseases from a historical } \\
\text { point of view in Turkey. Public Health Law No. } 1593 \text { provides } \\
\text { the basis for policies developed in the field of rare diseases. In } \\
\text { the early } 2000 \text {, genetic screening programs have been launched } \\
\text { (neonatal metabolic and endocrine disease, inherited blood } \\
\text { diseases, biotinidase deficiency, phenylketonuria, congenital } \\
\text { hypothyroidism, adrenal hyperplasia, cystic fibrosis, etc.). Since } \\
\text { 2007, Turkey has been a member of Orphanet. The Draft Guide } \\
\text { to Orphan Drugs was published by the Ministry of Health in } \\
\text { 2009. Since } 2014, \text { the public authorities, universities and NGOs } \\
\text { have been particularly interested in rare diseases. The civil } \\
\text { society initiative 'Rare Diseases Network' was established in } \\
\text { 2018 under the leadership of patients and their families. Some } \\
\text { reports on rare diseases were published by TÜHKE and the } \\
\text { TAÇESE in 2019. The Parliamentary Investigation Commission } \\
\text { has been set up to determine the situation of some rare diseases. } \\
\text { The Rare Diseases Department was established within the } \\
\text { Ministry of Health in 2020. It is recommended that the National } \\
\text { Action Plan on Rare Diseases and Orphan Drugs should be } \\
\text { implemented to develop policies, in particular access to } \\
\text { healthcare services and provide economic and psychosocial } \\
\text { support. }\end{array}$ \\
\hline
\end{tabular}

${ }^{1}$ Lecturer, Health Sciences Faculty, Başkent University, Ankara. mdpak @ baskent.edu.tr / Orcid Number: 0000-0001-7060-3729

${ }^{2}$ Lecturer, Vocational School of Health Services, Istanbul Okan University, Istanbul. Ph.D. Student, Health Sciences Faculty, Istanbul University - Cerrahpaşa, Istanbul. ozgurince@yahoo.com Orcid Number: https://orcid.org/0000-0002-6875-9115 
The term 'rare disease' (RD) is used to describe diseases that occur in a small number of people in the general population of a society. These diseases are also referred to as orphan diseases. To define them in different parts of the world, different prevalence is accepted. For example, diseases are seen in 1/200.000 people in Europe, 1/2.500 people in Asia are classified as rare. On the other hand, the World Health Organization (WHO) considers RD to have a prevalence of between 6.5/100.000 and 1/100.000 (as cited in Numanoğlu, 2019). Rare Diseases Report published by Turkish Health Institutes (Türkiye Să̆llk Enstitüleri Başkanliğl) (TÜSEB) in 2019, the prevalence of RD in Turkey is 38/100.000. (Satman et al., 2019). Despite the low incidence of RD, there are currently more than 10.000 different types of RD (Haendel et al., 2019) and about 400 million people worldwide are living with a rare disease (GARD, 2017). Approximately seven million people in Turkey have a rare disease (Satman et al., 2019).

The fact that most of them are of genetic origin, that they are chronic, degenerative, and progressive, and that they can be seen both in childhood and adulthood, are among the fundamental characteristics of RD (Shire, 2013; Pogue et al., 2017). Some serious problems are experienced by individuals with RD. The first of these relates to RD diagnosis. It is difficult to diagnose $\mathrm{RD}$, and the diagnosis time is long, and these diseases can be misdiagnosed (EURORDIS, 2009). The absence of sufficient laboratory tests or imaging methods to diagnose RD is one of the reasons for this. The second problem relates to treatment (Ayme et al., 2008). In the treatment of RD, high-cost medical products called 'orphan drugs' are used. The production, procurement and health insurance coverage of orphan drugs is time-consuming and expensive (Linertová et al., 2017). The third problem is that the number of healthcare institutions and professionals working in the field of RD is limited (Dharassi et al., 2017). As a result, these diseases also affect the healthcare system and healthcare providers. The lack of RD knowledge, guidance, and training makes it more difficult to diagnose and treat these diseases. Another critical issue is the psychosocial difficulties arising from RD (Aujoulat et al., 2012). In patients with RD and caregivers, the quality of life decreases, economic problems are encountered, levels of stress, anxiety and depression, and the burden of caregivers increases (Anderson et al., 2013; Bogart \& Irvin, 2017; Allotey et al., 2018). When all these factors are taken into account as a whole, RD is accepted globally as an important public health problem. In the field of RD, this situation requires the development of customized health policies. The aim of this study is to explore the historical perspective of health policies in Turkey with regard to RD. First of all, this study will highlight the basic principles of health policy, present health policy approaches related to $\mathrm{RD}$, and provide information on the political actors in the field of RD.

\section{The Background of Health Policy of Rare Diseases}

When certain stages come together, policy formation occurs. This process is expressed by Tengilimoğlu and Güzel (2020) as The Stages Model in Health Policy Making.' These stages consist of four stages: Agenda Setting, Policy Formulation, Policy Implementation, and Policy Evaluation (Figure 1).

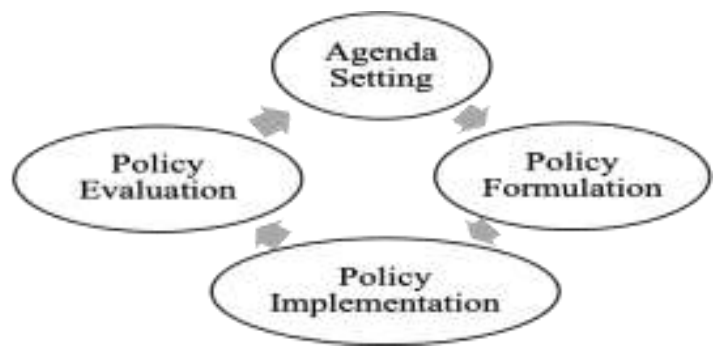

Figure 1. The Stages Model in Health Policy Making (Tengilimoğlu and Güzel, 2020)

Setting the agenda is the first step in policymaking. Considering a small number of issues out of many societal issues and potentially worthy of policymakers' consideration, the agenda setting (Buse et al., 2012; Princen, 2007). An important part of policymaking is the setting of agendas for politicians, authorities and interest groups. This stage is also important for the strategies that political actors pursue (Princen, 2007). Legislative and other decision-making bodies ensure the design of policies in the policy-making phase and manage the process of putting policies into practice (Walt et al., 2008).

Actors have an important role to play in the formulation of health policies. Actors who are often part of a network and influence the process of policy making can sometimes be part of a network and have the role of decision-maker or consultant at times. Legislative and executive bodies, the Ministry of Health, the judiciary, the political parties, the bureaucrats, the media, interest groups, nongovernmental organizations and international organizations are key players in Turkey's health policy (Tengilimoglu and Güzel, 2020).

This will lead to the creation of a dynamic environment for the provision of healthcare services, in particular in the diagnosis and treatment processes, and to the definition of the health policy framework in RD (Pejcic et al., 2017). Forman et al. (2012) demonstrate that some key points are needed to adapt $\mathrm{RD}$ to health policies:

- Although its prevalence in the general population is low, $\mathrm{RD}$, which affects about $8 \%$ of the 
population, should be considered as a public health problem by health policy authorities.

- Attention should be paid to fairness and justice in accessing healthcare services for individuals with RD. It should be acknowledged that it is a human right to receive good healthcare for these patients and that special health policies should be developed to accommodate their requirements.

- Research and development activities in the diagnostic and treatment processes of RD should be effective. Countries should implement programs to support and encourage research and development $(R \& D)$ in the field of $R D$.

- Individuals with RD are struggling not only with medical problems but also with psychosocial and economic problems. There is therefore and the need for a comprehensive approach to service provision.

- Information is very important for healthcare professionals and patients/caregivers alike. It is therefore necessary to ensure a sustainable flow of information in the RD.

- Patient organizations are important to individuals with RD. Patient groups should be included at all stages of policy and service development.

A standard public health approach for other diseases that are common or tend to cluster may not apply to RD. Due to the limited number of diagnostic, treatment and rehabilitation services in the field of RD and the problems associated with how to reach a geographically dispersed patient population, it is necessary to develop service delivery systems that meet different needs. The development of health policies to support public health approaches aimed at reducing the burden of RD is at a crucial point.

The beginning of the RD International Health Policy Regulations is based on the Orphan Drug Act, published by the United States in 1983. The European Union (EU) countries, on the other hand, have been developing health policies for RD since 1990. Examples of such policies are the Community action program in the field of public health (2003-2008), the Community action program in the field of public health (2008-2013), the Rare Diseases Task Force, the European Union Committee of Experts on Rare Diseases (EUCERD), the Research Framework Programmes, ERN and EUROPEAN (Orphanet, 2013). There are also health policies in Turkey in the field of RD. The aim of this study is to reveal the historical perspective of the relevant health policies with RD in Turkey. In this study, RD health policies in Turkey will be outlined to cover the 1930-2000, 2000-2015, and post-2015 periods.

\section{Historical Development of the Health Policies of Rare Diseases in Turkey}

Health policies for RD developed in Turkey have evolved since the 1930s. In this part of the study, health policies in the field of RD are reviewed to cover the period 1930-2000, 2000-2015 and post2015 .

\section{Health Policy of Rare Diseases between 1930- 2000}

The origin of RD health policy in Turkey is based on the early years of the Republic. Public Health Law (Umumi Hifzıssihha Kanunu) No. 1593, first published in 1930, provides a framework for the delivery of healthcare services. The legal regulation has established the infrastructure of the services to be provided for the diagnosis, treatment and rehabilitation of diseases. It is emphasized that various screening programs should be prepared in particular for the early diagnosis of diseases in children.Among all the motivations behind the implementation of these screening programs are to understand what is causing $\mathrm{RD}$, to identify people suspected of RD, and to provide early diagnosis. Screening programs have begun to be developed to diagnose $\mathrm{RD}$ seen in childhood and to extend over the years to include larger parts of the community.

The Ministry of Health is continuing studies under the 'Neonatal Metabolic and Endocrine Disease Screening Program.' The first of the studies carried out under the newborn screening programs is the Phenylketonuria Screening Program, which was launched in 1987. In 1993, the program was spread across the country. A blood sample is taken from the heel stick test for newborns in the screening program and the level of phenylalanine in the blood is checked. If the level of phenylalanine is high, a special feeding program is applied to infants (General Directorate of Public Health, 2018).

Another important area in the diagnosis of $\mathrm{RD}$ is related to hereditary blood diseases. These practices are based on Combating Hereditary Diseases (Kalıtsal Hastalıklarla Mücadele Kanunu) Law No 3960, which has been introduced in 1993. Within the context of this legal regulation, it has been stated that 'the state shall fight against all hereditary blood diseases, including thalassemia and sickle cell anemia and other hereditary diseases that cause disability, within the scope of preventive healthcare services.' Thalassemia centers have been established in Antalya, Antakya, Mersin and Muğla in 1994 (General Directorate of Public Health, 2018).

\section{Health Policy of Rare Diseases between 2000- 2015 \\ Screening programs for hereditary blood disorders continued in the early 2000s. The Hemoglobinopathy Control Program and the Diagnosis and Treatment Centers Regulation have been published in 2002 and}


the Hemoglobinopathy Prevention Program (2003) was implemented. In 2004, the Newborn Hearing Screening Program has been carried out as part of a pilot study in Ankara and began offering services in a national screening program across Turkey in 2008 (General Directorate of Public Health, 2018).

The 'Neonatal Screening Program Circular' has been enacted by the Ministry of Health (coordinating the Directorate-General for Maternal and Child Health and Family Planning and chairing the Refik Saydam Hifzıssıhha Center (Refik Saydam Hifzissıhha Merkezi Başkanlı̆̆l) in 2006. A congenital hypothyroidism screening program has also been added to the Phenylketonuria screening program within the scope of this circular. Congenital hypothyroidism includes an important period of development in the prevention of mental retardation in childhood. The spread of the screening program is therefore important in terms of early diagnosis (Erçin \& Oval1, 2019). The second biotinidase deficiency screening program was launched in 2008 (Özaltun et al., 2015). Cystic fibrosis screening, a genetic disease that affects the glands, has the potential to disrupt the functioning of multiple organs in the body, particularly the lungs, has been added to screening programs in 2015 (General Directorate of Public Health, 2018).

The Health Transformation Program is a milestone in the provision of healthcare services in Turkey that took place in 2003. Staged healthcare services have therefore been introduced; the principles and procedures for the reimbursement of health expenditure have been laid down within the scope of health insurance. Healthcare services for RD are now being offered as part of this transformation.

The acceleration of the international dimension of RD-related health policy studies in 2005 corresponds to the start of full accession negotiations in Turkey's European Union (EU). During this period, studies on the prevalence of $\mathrm{RD}$, diagnostic and treatment methods in EU countries are continuing rapidly. An international coding system has been put in place to track these diseases, encourage information sharing and set up a database for the follow-up of these diseases. In this context, many patients in the world, including Turkey, have switched to the ICD-10 code tracking system (Soyer, 2019). In 2007, Turkey was a member of Orphanet. This is a significant development in the international arena (Orphanet, 2020). The Technical Assistance Information Exchange Instrument of the European Commission (TAIEX) has been organized by the Ministry of Health in 2009. A structure was established in this workshop to encourage the use of Orphanet in the field of RD.

Studies on the problems experienced by rare disease patients and families were conducted in 2014. For example, a meeting was organized between the Ministry of Health and the Department of Patient
Rights and Medical Social Services to improve the quality of life of individuals with RD. It has been concluded at the meeting that diagnosis and treatment services should be enhanced. The same year, at the $1^{\text {st }}$ Turkish Medical World Congress, RD has been put on the agenda. In this scientific meeting, working groups were formed on the basis of an examination of different countries' examples of policies and services for RD.

\section{Health Policy of Rare Diseases between 2015 - 2020}

Since 2015, the training of decision makers, public authorities, universities and non-governmental organizations in health policy on RD has been accelerated. TÜSEB established the Turkish Institute for Public Health and Chronic Diseases (Türkiye Halk Să̆lı̆̆l ve Kronik Hastalıklar Enstitüsü) (TÜHKE) in 2015. TÜHKE aims to develop policies for health in RD. In the same year, at the $2^{\text {nd }}$ Turkish Medical World Congress, the "Rare Diseases Study Group" was established. The most significant results of this study relate to the limited epidemiological data relating to $\mathrm{RD}$ in Turkey. The report proposes to increase epidemiological studies, raise awareness and increase the level of knowledge in society and healthcare personnel, train professionals, develop screening programmes, promote research and development, set up multidisciplinary reference centers and lay down legislation on orphan drugs. It is essential to set up a national RD action plan, to open reference centers, to set up an information network and to set up incentives to develop health policies related to $R D$.

Awareness has begun to increase in the field of RD since 2016. The events organized on Rare Diseases Awareness Day since 2016 have been hosted by public authorities, universities, and non-governmental organizations. Furthermore, in the activities carried out by both the Directorate-General of Health Services and the Health Command of the Turkish Armed Forces (Türk Silahlı Kuvvetleri Sağllk Komutanlığl), the concerns and needs of people with RD have been identified. Istanbul University, Istanbul Faculty of Medicine, Experimental Medicine Research Institute, and Orphanet-Turkey organized the Rare Diseases Symposium that same year.

In 2017, scientific meetings continued the development of RD-related health policies. RD has been discussed at a panel held in cooperation with the Directorate General of Health Services of the Ministry of Health and TÜSEB. Also within scope of the panel, $\mathrm{RD}$ national plans have been indicated by speakers from different countries. Challenges in clinical and laboratory applications, orphan drugs, and R\&D activities have been expressed by the participating researchers from Turkey. The studies on the National Action Plan for Rare Diseases have been discussed in the 'Rare Diseases Workshop' with a small group of 
institutions and organizations and an inadequate group to solve the problems (Ministry of Health - General Directorate of Healthcare Services, 2017). The main topics on RD as medical issues such as registry studies, epidemiological field studies, chronic rheumatic diseases, diagnosis and treatment guidelines, cohort studies and also big data, costeffective applications, and quality in R\&D topics have been discussed at the Turkish Medical World Congress in the same year. The workshop report focused on possible developments in RD with cohort studies and discussed the potential benefits that can be achieved through the combination of certain cohort studies with the Genome Project. It has been stated that new studies should be carried out with regard to cost-effective services (TÜHKE, 2017).

It has been continued to develop screening programs for RD in 2017. In this frame of reference, within the scope of newborn screening programs, a pilot study for Adrenal Hyperplasia has been initiated. Pilot implementation was carried out in 14 provinces in 2018. Moreover in 2019, pilot implementation was carried out in 22 provinces. The purpose of the screening programs is to prevent mental retardation, brain injury and irreversible medical damage, while at the same time reducing the socio-economic aspects of these diseases. Approximately 4.500 children can be preserved annually thanks to this screening program (Ministry of Health - General Directorate of Healthcare Services, 2020).

Health policy actors are not only limited to a group of public institutions and organizations and politicians, but also include a number of stakeholders (Aba, 2018). In health policy, for instance, studies conducted by universities are also effective. The Rare Diseases and Orphan Drugs Application and Research Center (Nadir Hastalıklar ve Yetim Illaçlar Uygulama ve Araştırma Merkezi) (ACURARE), which has been operating under the University of Acibadem since 2017, is among the actors affecting RD policy. ACURARE is continuing its research into the treatment and diagnosis of orphan drugs and diseases (ACURARE, 2018). Scientific meetings on RD are also on the rising trend in 2018. For instance, within the scope of the Common Solution in Health Meetings, the Private Hospitals and Health Institutions Association (Özel Hastaneler ve Sağlık Kuruluşlar Derneği) (OHSAD) addressed the issue of diseases. It has been emphasized that more attention should be paid to RD in the workshop where the 2023 Health Policies Vision has been discussed with the relevant stakeholders. The other RD-related subjects discussed in the workshop have been RD hospitals, treatment protocols and cost issues (OHSAD, 2018). In 2018, TÜHKE's First Scientific Board Meeting provided the necessary information for establishing health policies in the field of RD. In terms of its establishment mission, the role of TÜHKE in RD policy is crucial. It contributes to the formation of health policies through its activities, activities and opinions. The importance of $\mathrm{R} \& \mathrm{D}$ studies for $\mathrm{RD}$, problems in reimbursement systems, problems in the follow-up of adults with RD, problems arising from consanguineous marriages, the importance of screening programmes, centers of excellence in $\mathrm{RD}$, the creation of a primary care follow-up model in RD and the integration of health services have been discussed (TÜHKE, 2018). On RD Day in 2018, activities have been carried out by the Turkish Institute of Mother, Child and Adolescent Health (Türkiye Anne, Çocuk ve Ergen Sağlığl Enstitüsü) (TAÇESE). The Ankara Institutions' Rare Diseases Recording Systems Meeting and Rare Disease Capacities Workshop have been organized within the scope of this activity (TAÇESE, 2018).

Patient advocacy organizations are another important factor in health policy. These organizations have a key role to play in R\&D activities, particularly in the fields of biomedical science and pharmaceuticals (Koay \& Sharp, 2013). Patient associations have recently raised awareness of RD and influenced policy makers to address the problems experienced by people with RD. In 2019, some of the associations operating in the field of RD united under the Rare Diseases Network (Nadir Hastalılar A $\breve{g l}$ ). Rare Diseases Network was formed by Albinism Association (Albinizim Derneği), Cystic Fibrosis Family Solidarity Association (Kistik Fibrozis Aile Yardımlaşma ve Dayanışma Derneği) (KIFDER), Mucopolysaccharidosis Lysosomal Storage Diseases Association (Mukopolisakkaridoz Lizozomal Depo Hastalıklart Derneği)(MPS - LH), the Combating NCL Disease and Solidarity Association (NCL Hastalığı ile Mücadele ve Dayanışma Derneği), PKU Family Association (PKU Aile Derneği), Pulmonary Hypertension and Scleroderma Association (Pulmoner Hipertansiyon ve Skleroderma Hasta Derneği) (PAHSSc), the Cystinosis Patients Association (Sistinozis Hastalarl Derneği), the Association for Combating SMA Disease (SMA Hastalı̆̆ ile Mücadele Derneği) and I'm Happy with My Face Association (Yüzümle Mutluyum Derneği). The aim of the Rare Diseases Network is to provide decision makers with solutions, to raise awareness in legislative studies, to carry out activities for the benefit of patients in diagnostic and treatment studies, and to improve the quality of life of patients (Nadir Hastalıklar Ağı, 2019).

Another significant development in the field of RD in 2019 has been the establishement of the council committee of the Turkish Grand National Assembly (TBMM) entitled "Treatment and Care Methods for ALS, SMA, DMD, MS and Other Diseases with Unknown Cure and Identifying the Problems and Solutions of People with These Diseases and Their Relatives". RD has been taken into consideration by political parties with this research commission, and the current problems have been systematically expressed in the parliament through a commission for 
the first time (TBMM $27^{\text {th }}$ Term Commission Reports, 2019). Studies on the Special Needs Report for Children (Çocuklar İçin Özel Gereksinim Raporu) (ÇÖZGER) have also been conducted in 2019, which is a significant development that has been implemented to benefit services for children with RD.

There have been developments in 2019 which will ensure that studies in the field of RD are supported by both national and international public institutions and organizations. For example, the STisNA - Istanbul Solution Platform for Undiagnosed and Rare Diseases (İstanbul Tanısız ve Nadir Hastalıklara Çözüm Platformu) has been established in the national field The project, supported by ISTKA (Istanbul Development Agency- İstanbul Kalkinma Ajansi), intends to generate an ecosystem that brings together all relevant RD actors (Acibadem University, 2019). The $1^{\text {st }}$ European Joint Program International Rare Diseases Research (EJP-RD) Joint Call has been published in the international arena.

Scientific meetings held by various disciplines in the field of RD have continued in 2019. For example, at the 5th Rare Diseases Symposium and Neurogenetics Course, organized by the Turkish Neurology Association (Türk Nöroloji Derneği), RD has been discussed in detail. In addition, in the program, the idea of a national Neurogenetic Network has also been discussed (https://norogenetik.org/).

In 2020, the Ministry of Health established the 'Autism, Special Needs in Mental Problems and Rare Diseases Department.' This unit can be expressed as an example of the fact that the issue is taken into account by public institutions and organizations and reciprocated by awareness activities.

\section{Health Policy of Orphan Drugs in Turkey}

Drugs used in the treatment of rare diseases are called orphan drugs. However, not all orphan drugs should be perceived as drugs used in the treatment of rare diseases. The issue of orphan drugs is a very broad subject and in this study, orphan drugs are discussed and summarized in the context of rare diseases. Global studies on orphan drugs have started to be seen since 1980 . The advocacy activities initiated by the patient organization National Organization for Rare Disorders (NORD) on these dates refer to activities aimed at implementing the orphan drug law. As a matter of fact, after these studies, one of the first studies on orphan drugs was the Orphan Drug Act (ODA) enacted by the USA in 1983 (Tambuyzer, 2010). After the orphan drug law was enacted in the USA, orphan drug laws were enacted in Japan in 1985, in Australia in 1997, and in the EU in 2000 (Aronson, 2006).

In Turkey, studies on orphan drugs started with the inclusion of orphan drugs in the Regulation on Clinical Trials issued in 2008. With the definition of orphan drug in this regulation, it is aimed to eliminate the problems related to the definition of the orphan drug (Köken et al., 2018). Studies on orphan drugs have been accelerated since 2009. During the same year, studies on the Draft Guide to Orphan Drugs were initiated by the Ministry of Health. Studies have been conducted on how to purchase orphan drugs, how to fund these drugs, how to provide incentives for the production of these drugs, and finally how to bring together and sustain rare disease patients and their drugs. Studies on orphan drugs continued rapidly throughout 2014. Rare Diseases and Orphan Drugs Symposium was organized by the Drug Awareness Development and Rational Medicine Association. Studies on orphan drugs have been continuing since 2014.

\section{DISCUSSION}

The aim of this study has been to present the historical perspective of the relevant health policies in Turkey with regard to RD. This study highlights basic principles of health policy, presents health policy approaches related to $\mathrm{RD}$, provides information on political actors in the field of $\mathrm{RD}$, and presents developments in health policy in the field of RD over historical periods.

Turkey's National Action Plan/RD Strategy is rather limited. Nevertheless, in the workshop held by the TÜHKE and at the Turkish Medical World Congress, the RD national action plan had been discussed but has not yet been implemented. Other studies in the literature, however; Gammie et al. (2015) and Khosla \& Valdez (2018) summarize in their study the situation in countries on the RD national plan. Nearly all EU Member States and many other countries (Australia, Ireland, Japan, Singapore, Taiwan, etc.) have national RD plans included in the study. Dharssi et al. (2017) stated that although some progress has been observed, there is no national plan for RD in Turkey. Orphanet (2009) recommended that states develop national plans and strategies to structure their responses to the challenges of rare diseases. Although Turkey has started to prepare its national plan for rare diseases, it should accelerate these studies and meet the needs of patients and their families (Yücel, 2019).

Turkey has orphan drugs-related legal regulation deficiencies. It is known to have been formed in 2016 as a draft text of orphan drug laws in Turkey. Czech et al. (2020) pointed out that Turkey's legislation lacks a strategy for orphan drugs. It was, however, emphasized that in accessing unapproved drugs, there 
is a well-structured three-step process. 43 are covered in Turkey by drug reimbursement. These drugs are not, however, marketed, 22 of which are in Turkey and are supplied by the Social Security Institution (Sosyal Güvenlik Kurumu) (SGK). Although reimbursement systems have problems, it is an indication that the supply of drugs has alternatives. The study stated that by stating that it allowed access to and use of unlicensed orphan drugs, legal flexibility was provided. Despite all these developments, the problems experienced about orphan drugs carry the agenda of being a public health problem in Turkey. Dharssi et al. (2017) noted that the study of orphan drug-related processes in Turkey was indeed advancing faster than in the past. Given the legislative studies on orphan medicinal products, it can be seen that the Orphan Medicinal Products Law was enacted in the US in 1983 and that the Orphan Drug Products Regulation was published in the EU in 1999. (Rodwell and Ayme, 2015). In countries such as The Netherlands, Germany, and France, more than 100 orphan drugs are covered by reimbursement (Czech et al., 2020).

RD studies in Turkey focus on genetic screening programs. However, these screening programs do not include the diagnosis of many RDs. Dharssi et al. (2017) argued that R\&D activities for the diagnosis of $\mathrm{RD}$ are limited in terms of national initiatives in Turkey. Czech et al. (2020) indicated that six various types of RD in Turkey are included in the screening program. Taking into account health policy in different countries; Poland 28, Netherlands 20, Germany 15 and France 5 different types of programs to screen for rare diseases (Czech et al., 2020). Genetic screening programs are also important for frequent consanguineous marriages in Turkey (Dündar \& Karabulut, 2010). Dissemination of screening programs, development of diagnostic methods, increased awareness of healthcare professionals and improvement of treatment methods will also increase the chance of diagnosis and survival of rare diseases (Bülbül, 2019). However, it can be argued that the policies for genetic counseling services have not been well developed or that the agenda is not sufficiently set in this regard.

RD epidemiological studies in Turkey are limited. Dharssi et al. (2017) indicated that there are many problems with the RD registration system in Turkey. However, it has been stated that some registration projects (as TREAT-NMD and EUROCARE) are supported. Yavuz Çolak (2019) also states that the number of rare diseases in Turkey is not sufficiently known and that there are not enough epidemiological studies in rare diseases. As a consequence, epidemiological studies for $\mathrm{RD}$ in Turkey are incomplete and are very much needed.

In both medical and psychosocial fields in RD, research and development studies have an important place. The universities and public authorities in
Turkey offer a wide variety of opportunities to researchers in the field of $\mathrm{RD}$. Besides that, in the international projects for RD, Turkey is defined as 'underrepresented.' EJP-RD 2021 calls for review when applying for projects in countries where each country has a number of partners applying to Turkey are less likely to have initiatives in the field of rare diseases, as this limitation is further extended (EJP $\mathrm{RD}, 2020$ ). However, it is challenging to create research groups or networks (Castillo-Esparcia and López-Villafranca, 2016). Dharssi et al. (2017) asserts that in some countries, research and development activities are officially supported but not officially supported in Turkey. Ceylaner and Ceylaner (2019) state that due to the low number of employees in the field of rare diseases, the investments of pharmaceutical and large device companies in Turkey in $R \& D$ studies are low in this field.

The economic problems in RD are also crucial. Families are suffered with both indirect and direct economic costs (Köken, Hayırlıdağ, \& Büken, 2018). Nevertheless, it is noted that the regulations providing economic support to individuals with RD and their families are limited in health policy regulations. The financing of these diseases in Turkey, in particular drugs, therapies, nutrition and physical therapy costs, is seen as an improvement that needs to be covered by payment systems. In order to solve the economic problems experienced by people with rare diseases and their families, the scope of reimbursement systems in health policies should be expanded and all patients should be included in this scope (Güngör, Tunca, \& Öcan, 2019).

The intersection of RD-related health policies and social policies are insufficient. Health policies must be developed in conjunction with social policies in the face of RD problems. Limited information, challenges in accessing healthcare services, limited diagnostic and treatment processes, and severe psychosocial and economic problems are increasing the importance of this integration. Aksu (2019) suggested that daycare services, socialization and rehabilitation centers, summer camps and training activities for individuals with RD be part of social policy as well as health policy in Turkey.

In setting the agenda among health policy actors, the roles of rare disease patient groups may be determinant. In recent years, studies in this field have gained momentum and patient organizations have been organized to affect health policies and increase awareness. Different achievements, such as the commission formed by the Turkish Grand National Assembly, have been achieved as a result of studies by patient organizations, the Rare Diseases Network, and other NGOs. In addition, by using the written and visual media efficiently, patient organizations have affected decision makers and bureaucracy in diseases such as SMA (Yıldız \& Yalçın, 2020). When the literature is reviewed, however, patient organizations 
date back to ancient times in the field of RD. It is stated that in the 1980s, patient organisations historically emerged in the USA and then spread to countries in Europe and the Far East (Huang et al., 2019). In countries like Japan (1993), Australia (1998), and EU member states, the legislation enacted through this movement has set an example and inspired legal regulations (2000). The studies attracted decision-makers' attention and raised awareness among other stakeholders (medical and scientific communities, industry, etc) (Choudhury \& Saberwal, 2019). It is critical for the development of RD NGOs in Turkey. Within the scope of collective action awareness, it is necessary to have information about non-governmental organizations in line with the illness, to encourage patients and their families to actively participate in these organizations, and even to support them to establish non-governmental organizations (Özden, Tekindal, \& Çoban, 2019).

In the public sector in the development of health policy about RD in Turkey in the area began to increase. Awareness is also positive for activities such as panels and symposiums organized in universities, patient organization activities, and studies of other actors. However, considering the existence of activities launched at the end of the $20^{\text {th }}$ century in 1980 in the US and the EU, Turkey has many steps to take in the development of health policy in the field of RD.

\section{CONCLUSION}

This study has demonstrated that RD-related health policies with a historical perspective in Turkey include activities carried out by health policy actors associated with RD. It includes the formulation of RD health policy in Turkey with contributions from public institutions and organizations, universities, research centers and NGOs. These studies focus primarily on genetic screening for early diagnosis, healthcare services processes and principles to be offered in the diagnosis and treatment of RD, orphan drugs, solving the problems of people with RD and their families, and activities to raise awareness.

As a consequence of efforts to influence the agenda and agenda-setting activities, health policies are emerging. The emphasis on health policy in the field of RD in Turkey is on important issues. To solve these issues, the following suggestions can be developed:

- Taking into consideration that the epidemiological studies on RD are limited, more data are needed in the planning of the services to be provided to these patients. Comprehensive epidemiological studies on $\mathrm{RD}$ should be included in the health policy agenda.

- It is recommended that a national RD action/strategy plan be developed.

\section{Conflict of Interest:}

The authors declare that they have no conflict of interest.

\section{Ethical Approval:}

All procedures have performed in accordance with the ethical standards and with the Helsinki Declaration and its later amendments or comparable ethical standards.

Funding:

No financial support was used in this study.
- It is known that not all orphan drugs belong to rare diseases. However, developments in orphan drugs will reduce the problems. So, it is recommended that the legal provisions on orphan drugs be finalised.

- Early genetic screening programs for RD should be extended.

- Informing individuals and families about consanguineous marriages on RD and developing policies to expand genetic counseling services are recommended.

- Increased number of studies to support research and development activities in RD are recommended.

- It is necessary to integrate health policies and social policies with one another and to act with a holistic approach to health.

- It is recommended that policies to eliminate funding problems should be broadened (especially orphan drugs, treatment expenses, medical equipment, nutrition, and physical therapy costs).

- It is recommended that health policies that support patient organizations be developed. 


\section{REFERENCES}

1. Aba, G. (2018). Sağlık Politikası ve Planlaması. Nobel Yayıncilık.

2. Acrbadem Üniversitesi. (2019). İSTisNA-İstanbul Tanısız ve Nadir Hastalıklara Çözüm Platformu Fizibilite Desteği Projesi. https://www.acibadem.edu.tr/haberler/istisna-istanbul-tanisizve-nadir-hastaliklara-cozum-platformu-fizibilite-destegi-projes

\section{ACURARE.} (2018). Hakkında. https://www.acibadem.edu.tr/rare/hakkinda/merkez-tanimi-vekurulus-gerekcesi.

4. Aksu, B. (2009). Rare Disease and Orphan Drug Situations in Turkey and around the World. Aurum Journal of Health Sciences, 1(2), 95-109.

5. Allotey, P. A., Allotey-Reidpath, C. D., \& Reidpath, D. D. (2018). Health systems implications of rare genetic conditions in low-and middle-income countries: a case study approach. Critical Public Health, 28(2), 248-252. https://doi.org/10.1080/09581596.2017.1344772

6. Anderson, M., Elliott, E. J., \& Zurynski, A. Y. (2013) Australian families living with rare disease: experiences of diagnosis, health services use and needs for psychosocial support. Orphanet Journal of Rare Diseases, 8(22), 1-9. https://doi.org/10.1186/1750-1172-8-22

7. Aronson, J. K. (2006). Rare Diseases and Orphan Drugs. British journal of clinical pharmacology, 61(3), 243-245.

8. Aujoulat, I., Young, B., \& Salmon, P. (2012). The psychological processes involved in patient empowerment. Orphanet Journal of Rare Diseases, 7(2), 31. https://doi.org/10.1186/1750-1172-7-S2-A31

9. Aymé, S., \& Rodwell, C. (2012). Report on the State of the Art of Rare Disease Activities in Europe of the European Union Committee of Experts on Rare Diseases. https://op.europa.eu/en/publication-detail//publication/67da4f31-41ff-4b77-a9ca-dfda08582219/languageen

10. Aymé, S., Kole, A., \& Groft, S. (2008). Empowerment of patients: lessons from the rare diseases community. The Lancet, 371(9629), 2048-2051. https://doi.org/10.1016/S01406736(08)60875-2

11. Bogart, K. R., \& Irvin, V. L. (2017). Health-related quality of life among adults with diverse rare disorders. Orphanet journal of rare diseases, 12(1), 177. https://doi.org/10.1186/s13023017-0730-1

12. Bülbül, S. (2019). Cocukluk Dönemi Nadir Hastalıkları: Mevcut Durum, İzlem Özellikleri Ve Tedavi Yaklaşımları. Ö. İnce, \& M. D. Pak (Eds.), Tüm Yönleriyle Nadir Hastalıklar içinde (pp. 52-72). Ankara: Nobel Akademik Yayıncılık.

13. Buse, K., Mays, N., \& Walt, G. (2012). Making health policy. McGraw-hill education (UK). London.

14. Castillo-Esparcia, A., \& López-Villafranca, P. (2016). Communication strategies employed by rare disease patient organizations in Spain. Ciência \& Saúde Coletiva, 21, 2423 2436. https://doi.org/10.1590/1413-81232015218.19852015

15. Ceylaner, S. \& Ceylaner, G. (2019). İlaç Ve Medikal Cihaz Geliştirme Süreçleri, Yeni Teknolojiler Ve Bilimsel Çevre Koşulları. Ö. İnce, \& M. D. Pak (Eds.), Tüm Yönleriyle Nadir Hastalıklar içinde (pp. 314-326). Ankara: Nobel Akademik Yayıncilık.

16. Choudhury, M. C., \& Saberwal, G. (2019). The role of patient organizations in the rare disease ecosystem in India: an interview based study. Orphanet journal of rare diseases, 14(1), 117. https://doi.org/10.1186/s13023-019-1093-6

17. Çocuklar için özel gereksinim raporu (ÇÖZGER). (2019). Say1:30692

18. Czech, M., Baran-Kooiker, A., Atikeler, K., Demirtshyan, M., Gaitova, K., Holownia-Voloskova, M., ... \& Sykut-Cegielska, J. (2020). A review of rare disease policies and orphan drug reimbursement systems in 12 Eurasian countries. Frontiers in public health, 7, 416. https://doi.org/10.3389/fpubh.2019.00416

19. Dharassi, S., Wong-Rieger, D., Harold, M. \& Terry, S. (2017) Review of 11 national policies for rare diseases in the context of key patient needs. Orphanet Journal of Rare Diseases, 12 (63). https://doi.org/10.1186/s13023-017-0618-0
20. Dündar, M., \& Yeșim Karabulut, S. (2010). Rare disease and orphan drugs in Turkey; medical and social problem. Erciyes Medical Journal, 32(3), 195-200.

21. EJP - RD. (2020). Call for Proposals 2021. https://www.ejprarediseases.org/wpcontent/uploads/2020/12/JTC2021-1-Call-text-VF.pdf

22. Erçin, S. \& Ovalı, F. (2019). Yenidoğan Taramaları. Klinik Tıp Pediatri Dergisi, 11(4), 193-199.

23. EURORDIS. (2009). The voice of 12,000 patients. Experiences and expectations of rare disease patients on diagnosis and Care in Europe: Eurordis; 2009.

24. EURORDIS. (2017). What is a rare disease? http://www.eurordis.org/sites/default/files/publications/Fact_Sh eet_RD.pdf, Erişim tarihi: 12.12.2020.

25. Forman, J., Taruscio, D., Llera, V. A., Barrera, L. A., Coté, T. R., Edfjäll, C., ... \& International Conference for Rare Diseases and Orphan Drugs (ICORD). (2012). The need for worldwide policy and action plans for rare diseases. Acta Paediatrica, 101(8), 805-807. https://doi.org/10.1111/j.16512227.2012.02705.x

26. Gammie, T., Lu, C. Y., \& Babar, Z. U. D. (2015). Access to orphan drugs: a comprehensive review of legislations, regulations and policies in 35 countries. PloS one, 10(10), e0140002. https://doi.org/10.1371/journal.pone.0140002

27. GARD. (Genetic and Rare Diseases Information Center) (2017). GARD FAQs about rare diseases https://rarediseases.info.nih.gov/diseases/pages/31/faqs-aboutrare-diseases

28. Güngör, D., Tunca, A.B., \& Özcan, E. (2019). Sağlikta Dönüşüm Ve Nadir Hastalığa Sahip Bireylere Yönelik BiyoIktidar Pratikleri. Ö. İnce, \& M. D. Pak (Eds.), Tüm Yönleriyle Nadir Hastalıklar Içinde (pp. 170-182). Ankara: Nobel Akademik Yayıncılık.

29. Haendel, M., Vasilevsky, N., Unni, D., Bologa, C., Harris, N., Rehm, H., ... \& Dawkins, H. (2019). How many rare diseases are there?. Nature Reviews Drug Discovery 19, 77-78. https://doi.org/10.1038/d41573-019-00180-y

30. Halk Sağlığı Genel Müdürlügü $\quad$ (2018). https://hs gm.saglik.gov.tr/tr/cocukergen-tpliste/yenidogan_tarama_programi.html.

31. Halk Sağlığı Genel Müdürlüğü. (2018). Yenidoğan Metabolik ve Endokrin Hastalı Tarama Programı (NTP). https://hs gm.saglik.gov.tr/tr/cocukergen-tpliste/yenido\%C4\%9Fan-i\%CC\%87\%C5\%9Fitmetaramas\%C4\%B1-program\%C4\%B1.html

32. Huang, R., Wei, Y., Hu, J., Kong, F., He, J., Yang, Y., ... \& Kang, Q. (2019). The progress of, challenges faced by, and future of rare disease patient organizations in China. Intractable \& Rare Diseases Research, 8(2), 158-160. https://doi.org/10.5582/irdr.2019.01069

33. Türk Tip Dünyası Kurultayı. (2014). Kurultay Raporu. https://docplayer.biz.tr/3414174-Turk-tip-dunyasi-kurultayi-2931-ekim-2014-istanbul.html.

34. Türk Tıp Dünyası Kurultayı. (2015). Kurultay Raporu. https://disab.saglik.gov.tr/Eklenti/2101/0/2ttdkkitappdf.pdf

35. İlaç Bilincini Geliştirme ve Akılcı İlaç Derneği (2014). 'Nadir Hastalıklar ve Yetim İlaç Sempozyumu ve Yetim İlaç Yönetmelik Çalıştayı' Raporu. https://www.akilciilacdernegi.com/uploads/kongre/toplanti.pdf

36. İstanbul Üniversitesi Deneysel Tip Araştırma Enstitüsüİstanbul Tip Fakültesi-Orphanet. (2016). Türkiye Nadir Hastalıklar Günü Sempozyumu. http://cdn.istanbul.edu.tr/statics/www.istanbul.edu.tr/wpcontent/uploads/2016/02/nadir_hastaliklar_gunu_programi_29_ subat_2016_SON.pdf

37. Kalıtsal Hastalıklarla Mücadele Kanunu. (1993). Kanun no: 3960.

38. Khosla, N., \& Valdez, R. (2018). A compilation of national plans, policies and government actions for rare diseases in 23 countries. Intractable \& Rare Diseases Research, 7(4), 213-222. https://doi.org/10.5582/irdr.2018.01085

39. Koay, P. P., \& Sharp, R. R. (2013). The role of patient advocacy organizations in shaping genomic science. Annual 
review of genomics and human genetics, 14, 579-595. https://doi.org/10.1146/annurev-genom-091212-153525

40. Koçkaya, G., Atalay, S., Oğuzhan, G., Kurnaz, M., Ökçün, S., Gedik, Ç. S., ... \& Şencan, N. (2021). Analysis of patient access to orphan drugs in Turkey. Orphanet Journal of Rare Diseases, 16(1), 1-8.

41. Köken, A. H., Hayırlıdağ, M., \& Büken, N. Ö. (2018). Sağlık Hakkı Bağlamında Nadir Hastalıklar ve Yetim İlaçlar. Türkiye Klinikleri Journals Med Ethics Law Hist-Special Topics, 91-98.

42. Linertová, R., García-Pérez, L., \& Gorostiza, I. (2017). Cost-ofillness in rare diseases. In Rare Diseases Epidemiology: Update and Overview (pp. 283-297). Springer, Cham. https://doi.org/10.1007/978-3-319-67144-4_17

43. Nadir Hastalıklar A ğı. (2019). Hakkımızda https://www.nadirhastaliklaragi.org.tr/hakkimizda

44. Numanoğlu, R. (2019). Asya Ülkelerinde Nadir Hastalıklara Yönelik Politikalar. In:Özgür İnce, Merve Deniz Pak editors Tüm Yönleriyle Nadir Hastalıklar. Ankara: Nobel Yayıncılık, p.133-149.

45. OHSAD. (2018). OHSAD 2023 Sağlık Politikaları Vizyonu https://ohsadkurultayi.org/tr/2018-SUNUMLARI.html

46. Orphanet. (2013). About rare diseases policies. https://www.orpha. net/consor/cgi-

bin/Education_AboutRareDiseases.php?Ing=EN\&stapage=ST_ EDUCATION_EDUCATION_ABOUTRAREDISEASES_PO LICI

47. Orphanet. (2020). Orphanet Türkiye web sayfası giriş noktası. http://www.orpha.net/national/TR-TR/index/orphanett\%C3\%BCrkiye/

48. Özaltun, Ş.C., Güler, C., \& Şengelen, M. (2015). Sağlık taramaları.

http://www.halksagligi.hacettepe.edu.tr/diger/toplumayonelik/ta rama.pdf

49. Özden, S.A., Tekindal, M., \& Çoban, A.İ. (2019). Nadir Hastalıklarda Sosyal Hizmet Müdahalesi Olarak Psikoeğitim ve Grup Çalışması. Ö. İnce, \& M. D. Pak (Eds.), Tüm Yönleriyle Nadir Hastalıklar içinde (pp. 193-205). Ankara: Nobel Akademik Yayıncılık.

50. Pejcic, A. V., Iskrov, G., Raycheva, R., Stefanov, R., \& Jakovljevic, M. (2017). Transposition and implementation of EU rare disease policy in Eastern Europe. Expert Review of Pharmacoeconomics \& Outcomes Research, 17(6), 557-566. https://doi.org/10.1080/14737167.2017.1388741

51. Pogue, R. E., Cavalcanti, D. P., Shanker, S., Andrade, R. V., Aguiar, L. R., de Carvalho, J. L., \& Costa, F. F. (2017). Rare genetic diseases: update on diagnosis, treatment and online resources. Drug discovery today. 23(1), 1-9. https://doi.org/10.1016/j.drudis.2017.11.002

52. Princen, S. (2007). Agenda-setting in the European Union: a theoretical exploration and agenda for research. Journal of European Public Policy, 14(1), 21-38. https://doi.org/10.1080/13501760601071539

53. Rodwell, C., \& Aymé, S. (2015). Rare disease policies to improve care for patients in Europe. Biochimica et Biophysica Acta (BBA)-Molecular Basis of Disease, 1852(10), 2329-2335 https://doi.org/10.1016/j.bbadis.2015.02.008

54. Satman, İ., Güdük, Ö., Yemenici, M., \& Ertürk, N. (2019). Nadir Hastalıklar Raporu. Ankara: TÜSEB (Türkiye Halk Sağlığı ve Kronik Hastalıklar Enstitüsü).
55. Shire. (2013). Rare disease impact report: Insights from patients and the medical community. California: Global Genes. https://globalgenes.org/wpcontent/uploads/2013/04/ShireReport-1.pdf

56. Soyer, T. (2019). Nadir Hastalıklarda Sinıflama ve Kodlama Sistemleri. In:Özgür İnce, Merve Deniz Pak editors. Tüm Yönleriyle Nadir Hastalıklar. Ankara: Nobel Akademik Yayıncilık

57. T.C. Sağlık Bakanlığı - Sağlık Hizmetleri Genel Müdürlüğü. (2017). https://hasta.saglik. gov.tr/TR-30120/uluslararasi-nadirhastaliklar-panel-ve-calistayi.html

58. T.C. Sağlık Bakanlığı - Sağllk Hizmetleri Genel Müdürlüğü. (2020). Yenidoğan Metabolik ve Endokrin Hastalık Tarama Programı (NTP). https://hsgm.saglik.gov.tr/tr/cocukergen-tpliste/yenidogan_tarama_programi.html

59. TAÇESE. (2018). 2018 Yılı Birim Faaliyet Raporu. https://www.tuseb.gov.tr/tacese/uploads/genel/files/tacese2018fr.pdf

60. TAIEX. (2009). European Neighbourhood Policy And Enlargement Negotiations. https://ec.europa.eu/neighbourhoodenlargement/tenders/taiex

61. Tambuyzer, E. (2010). Rare diseases, orphan drugs and their regulation: questions and misconceptions. Nature Reviews Drug Discovery, 9(12), 921-929.

62. TBMM. (2019). Türkiye Büyük Millet Meclisi Komisyon Tutanakları $27 . \quad$ Dönem. https://www.tbmm.gov.tr/develop/owa/komisyon_tutanaklari.tu tanaklar?pKomKod=1049\&pDonem $=27$

63. Tengilimoğlu, D., \& Güzel, A. (2020). Sağlık Politikası Belirleme Süreci ve Politikayı Belirleyen Aktörler. In Sağlık Politikası, Nobel Akademik Yayıncılık. Ankara.

64. TÜHKE. (2017). Türkiye Halk Sağlığı ve Kronik Hastalıklar Enstitüsü (TÜHKE) Calıştayı. https://www.tuseb.gov.tr/tuhke/uploads/genel/files/bilimsel_etk inlikler/TUHKE-Calistay-Raporu_IV-TTDK_28-29-102017.pdf

65. TÜHKE. (2018). 1. Bilim Kurulu Toplantı Raporu. https://www.tuseb.gov.tr/tuhke/uploads/genel/files/bilimsel_etk inlikler/birinci_bilim_kurulu_toplanti_raporu.pdf

66. Türk Nöroloji Derneği. (2019). 5th Rare Diseases Symposium and Neurogenetics Course. https://norogenetik.org

67. Umumi Hıfzıssıhha Kanunu. (1930). Kanun no: 1593, Resmî Gazete Sayısı: 1489

68. Walt, G., Shiffman, J., Schneider, H., Murray, S. F., Brugha, R., \& Gilson, L. (2008). 'Doing' health policy analysis: methodological and conceptual reflections and challenges. Health policy and planning, 23(5), 308-317. https://doi.org/10.1093/heapol/czn024

69. Yavuz Çolak, M. (2019). Nadir Hastalıklar Epidemiyolojisi. Ö. İnce, \& M. D. Pak (Eds.), Tüm Yönleriyle Nadir Hastalıklar içinde (pp. 15-25). Ankara: Nobel Akademik Yayıncılık.

70. Yıldız, G., \& Yalçın, S. (2020). Gazete Haberlerinin Sağlık Politikalarının Belirlenmesi ve Uygulanmasındaki Önemi: Milliyet Gazetesi MPS ve SMA Haberleri Örneği. Kurgu, 28(1), 286-304

71. Yücel, O. (2019). Nadir Hastaliklarin Kavramsal Çerçevesi. Ö. İnce, \& M. D. Pak (Eds.), Tüm Yönleriyle Nadir Hastalıklar içinde (pp. 15-25). Ankara: Nobel Akademik Yayıncılık. 